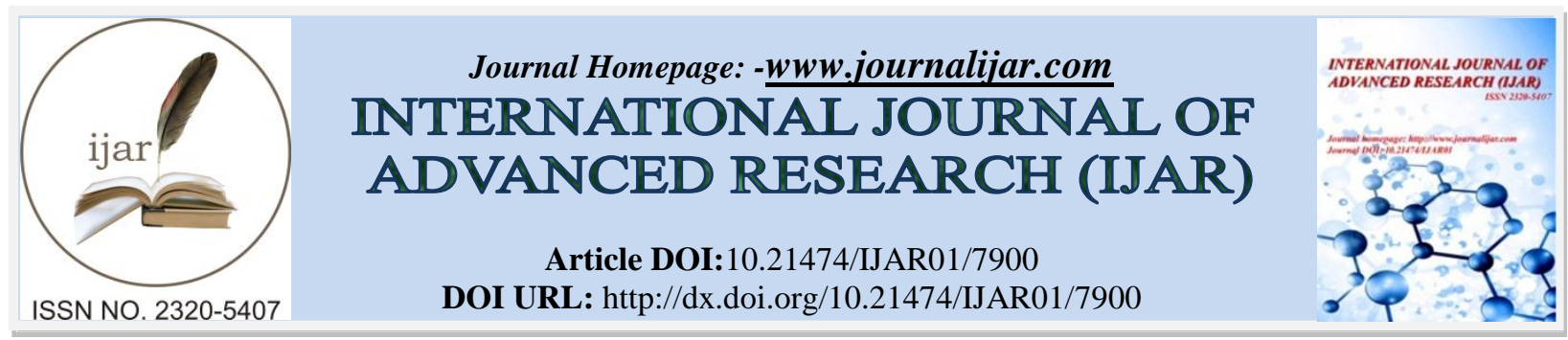

RESEARCH ARTICLE

\title{
CAMAT PERFORMANCE UNDERSTANDING IN DEVELOPMENT OF INFRASTRUCTURE IN SIDORUKUN VILLAGE, KECAMATANPOHUWATO REGENCY HANDLING.
}

Arman $^{1}$ and Purnamasari ${ }^{2}$.

1. Faculty of Social and Political Sciences, Ichsan University, Gorontalo-Indonesia.

2. IchsanPohuwato-Indonesia College of Economics.

\section{Manuscript Info}

Manuscript History

Received: 12 August 2018

Final Accepted: 14 September 2018

Published: October 2018

Keywords:

Performance, Infrastructure

Development

\section{Abstract}

Ensuring that the implementation of good governance activities was necessary for functional supervision in the government that can be carried out by internal and external auditors. This study aims to provide a review of the determinant factors in influencing the audit judgment of the government's external auditor. This research is a quantitative type. As many as 58 auditors from the State Audit Board of the Republic of Indonesia Representative of Southeast Sulawesi Province were sampled in this study. Data collection using a questionnaire instrument. And data were analyzed using Moderated Regression Analysis (MRA). The results of this study showed

Copy Right, IJAR, 2018,. All rights reserved.

\section{Introduction:-}

The application of the principles of good governance in the management of government becomes a major demand, because the community is beginning to be critical in monitoring and evaluating services from government agencies. On the other hand, the measurement of the success and failure of government agencies in carrying out their main tasks and functions is difficult to do objectively, because the performance measurement system has not been implemented, which can inform the objective and measurable success rate of the implementation of programs in a government agency. Organizations are established as a place to achieve a goal or several goals.

Performance camat in infrastructure development in the villages, basically those efforts are directed to support the State administration established on fluency and coherence implementation of the tasks and functions of sub-district are in realizing the administration increasingly reliable, professional, efficient, effective and responsive to the aspirations of the people and the dynamics of change environment. One symptom that appears in this shifting process is the increasing attention of cultural aspects in organizational studies. Not only as an important part in organizational studies, but the concept of culture is used as a metaphor to explain the embodiment and nature of the organization. Its use in organizational analysis, culture is not only seen as something that exists and lives in an organization, but also something that is used as a rationale in understanding the organization. As a variable in the organization, culture is studied as part of the overall organizational system. In this context, culture is seen as something that lives in an organization that binds all members of the organization in an effort to achieve common goals. Culture can also be seen as part of an organizational environment that affects organizational behavior and performance.

Inhibiting the performance of the camat in the development of infrastructure in the village becomes very important or in other words has a very strategic value in this study. Information about the factors that influence the 
performance of the apparatus is very important to know, so that the measurement of apparatus performance should be translated as an evaluation activity to assess or see the successes and failures of the implementation of tasks and functions imposed on them. Therefore performance is an analysis of the interpretation of the successes and failures of performance achievement.Appraisal of apparatus performance is a very important activity because it can be used as a measure of organizational success in achieving its mission.Republic of Indonesia Government Regulation Number. 41 of 2007 concerning the organization of regional apparatuses triggering or the apparatus of the regency/ city region in the sub-district area which is located under and is responsible to the regent / mayor through the subdistrict head.

Based on Government Regulation Number 19 of 2008 concerning Districts, in Article 14 paragraph (1) where the sub-district is a district / city regional apparatus as a regional technical implementer that has a particular work area and is headed by the Camat. The sub district organization is an element of the territorial line, the Camat performs the main tasks as a line element, namely "to do, to act" meaning that the Camat's activities and their ranks are operational, providing direct services to the community. Various efforts have been made by the government to form an ideal government apparatus in accordance with current demands. But in reality public complaints about the performance of government officials in serving often color the process of the relationship between those who serve and those served. The phenomenon that can almost be found in various government agencies, is also found in the working environment of the Pohuwato Regency Government, especially the Performance of Village Heads in Infrastructure Development in Sidorukun Village, RandanganSubdistrict, Pohuwato Regency, Sidorukun Village which is the object of this study. On the basis of the background of the above thoughts, the author is interested in conducting research with the problem of inhibiting the performance of the Village Chief in the infrastructure development of Sidorukun Village, District of Randangan, Pohuwato district.

\section{Literature Review \\ The ConceptPerformance}

The term performance is a translation of performance that is often interpreted by scholars as "appearance", "performance", or "achievement" (Yeremias T. Keban, 2004: 191). Etymologically, performance is a word which in Indonesian comes from the basic word "work" which translates words from a foreign language of achievement, it can also mean work. So that the notion of performance in the organization is the answer to the success or failure of the stated organizational goals ( www.wikipedia.com ).

In contrast to (Bernardin and Russel 1993: 379) in Yeremias T. Keban (2004: 192) defines performance as $a$ function of a specified job function or activity during a specified time period. In this definition, the aspect emphasized by the two authors is a record of the outcome or end result obtained after a job or activity is carried out for a certain period of time.

Thus the performance only refers to a series of results obtained by an employee during a certain period and does not include the personal characteristics of the employee being assessed. While SuyadiPrawirosentono (1999:2) defines performance as a performance, namely the work that can be achieved by a person or group of people in an organization, in accordance with the authority and responsibility of each, in order to achieve the objectives of the organization legally, not violate law and in accordance with morals and ethics. The definition of organizational performance proposed by Bastian in HesselNogi (2005: 175) as an illustration of the level of achievement of the implementation of tasks in an organization, in realizing the goals, objectives, mission and vision of the organization. In line with the opinion of Bastian in the Ness Hessel, the Encyclopedia of Public Administration and Public Policy in 2003 in Yeremias T. Keban (2004: 193), also mentions performance can provide an overview of how far the organization achieved results when compared to achieving the goals and targets set.

\section{Factors Affecting Performance}

Performance is an achievement or work result in activities or activities or programs that have been planned in advance to achieve the goals and objectives set by an organization and carried out within a certain period of time that is influenced by several factors. In Yeremias T. Keban (2004: 203) to conduct a more in-depth study of the factors that influence the effectiveness of performance appraisal in Indonesia, it is necessary to look at several important factors as follows:

1. Clarity of lawsuits or legislation to conduct appraisal correctly and appropriately. In reality, people judge subjectively and are full of bias but there is no legal rule governing or controlling the act. 
2. Human resource management that applies has functions and processes that determine the effectiveness of performance appraisals. The rules play concerning who should judge, when to judge, what criteria are used in the performance appraisal system are actually regulated in the human resource management. Thus human resource management is also the main key to the success of the performance appraisal system.

3. Conformity between the paradigms adopted by management of an organization with the aim of performance appraisal. If the paradigm adopted is still oriented to classical management, then the assessment is always biased towards the measurement of character or the character of the party being assessed, so that achievements that should be the main focus are less noticed.

4. Commitment of leaders or managers of public organizations to the importance of evaluating performance. If they always give a high commitment to the effectiveness of the performance appraisal, then the assessors who are under their authority will always try to do the assessment correctly and correctly.

5. According to Soesilo in HesselNogi (2005: 180), the performance of an organization is influenced by the following factors:

6. The organizational structure as an internal relationship related to the functions that carry out organizational activities;

7. Management policy, in the form of organizational vision and mission;

8. Human resources, which relate to the quality of employees to work and work optimally;

9. Management information system, which deals with data base management for use in enhancing organizational performance.

10. Facilities and infrastructure owned, which relate to the use of technology for organizing the organization in every organizational activity.

\section{Performance assessment}

According to Larry D. Stout in HesselNogi (2005: 174) suggests that the measurement or assessment of organizational performance is the process of recording and measuring the achievement of the implementation of activities in the direction of achieving mission (missionaccomplishment) through the results displayed in the form of products, services or a process. In contrast to the statement put forward by Bastian (2001: 330) in HesselNogi (2005: 173) that measurement and utilization of performance appraisal will encourage the achievement of organizational goals and will provide feedback for continuous improvement efforts. In detail, Bastian presents the role of assessing organizational performance measurement as follows:

1. Ensuring the understanding of the implementers and the measures used for achievement,

2. Ensuring the achievement of an agreed achievement scheme

3. Monitor and evaluate performance by comparison between work schemes and their implementation,

4. Provide objective rewards and penalties for the performance achievements that have been measured, in accordance with the agreed measurement system,

5. Making it a communication tool between subordinates and leaders in an effort to improve organizational performance,

6. Identify whether customer satisfaction has been fulfilled,

7. Assist in the organization's activities process,

8. Ensure that decision making has been carried out objectively,

9. Demonstrate improvements that need to be made,

10. Reveal the problems that occur, Once the importance of performance assessment for the sustainability of the organization in achieving its objectives, it is necessary to have performance measurement indicators that are used appropriately in certain organizations.

According to AgusDwiyanto (2006:49) assessment of the performance of public bureaucracy is not enough to be done by using indicators that are inherent in the bureaucracy, such as efficiency and effectiveness, but also must be seen from indicator indicators that are attached to service users, such as service user satisfaction, accountability and responsiveness. . Performance appraisal in terms of service users is very important because public bureaucracy also arises because the goals and mission of the public bureaucracy often not only has many stakeholders and have interests that often clash with each other causing the public bureaucracy to have difficulty formulating clear missions. As a result, the size of the performance of public organizations in the eyes of stakeholders also varies. 
And according to Ndraha, Taliziduha. (1991:32) The performance of the village head is to be able to do where:

1. Coordinating village community empowerment activities;

2. Coordinate efforts to ensure peace and public order;

3. Coordinate the implementation and enforcement of legislation;

\section{Village Infrastructure Development}

The definition of development is a systematic and sustainable / sustainable effort to create conditions that can provide a variety of legitimate alternatives for the achievement of the aspirations of every humanistic person (Anwar 2005: 34, In Relation to the Concept of Regional Development).TalidazuhuNdraha in Subroto (2001: 45) gives some of the criteria contained in the rural development, namely: 1 . The presence of active community participation in pembagunan, 2. There is a sense of responsibility towards the development of society, 3 . The ability of rural communities have grown untiuk can ditingkatka $\mathrm{n}$, 4. Physical infrastructure can be built and maintained, 5. A harmonious environment can be built and maintained

Whereas Mely G. Tan and Koentjaraningrat in Soebroto (2001: 60), provide several things that can be used to assess the success of rural community development, namely: 1 . The results of the reform business must be seen in a concrete manner in a short time, 2. Business renewal it must be beneficial for the community concerned, 3 . These efforts must not conflict with the system of cultural values and norms that are still valid in the village community

In line with the above presentation, the pela k pembagunan enforcing the government planned community participation is highly influence the success of the development process itself. Not only that, it requires good or good budgeting from the central level to the village level. The budge formulation process in the public sector, especially in local governance, is an important phase of the beginning of the financial management process. During the phase or step, it is very crucial for the budgeting process to harmonize perceptions among stakeholders on the achievements that will be made as well as there is a relationship between organizational goals and various programs to be implemented. (Octariani, Akram, \&Animah, 2017). The diversity of rural areas in Indonesia depends on a variety of typologies, which by Anwar (2005: 37). For this reason, Wresniwiro (2007: 45) proposes a concept of development to reduce spatial inequality by balancing urban development in an integrated manner. The spatial balance can be achieved if in rural development planning pay attention to various factors related and development directed to achieve the objectives: (1) equity, (2) growth, (3) linkages, (4) balance, (5) independence, and (6 ) sustainability.

\section{Research methods}

Based on the research background and the research framework as has been described in the previous chapter, then that becomes the object of research is $\mathrm{f}$ actor camat inhibiting performance in infrastructure development in rural sub-district SidorukunRandanganPohuwato and time of this study is \pm 3 months. This type of research is descriptive qualitative, using descriptive qualitative descriptive study method which describes the method directed to solve the problem by describing or describing the results of the research. The accuracy of the determination of this method is based on the opinion of WinarnoSurachmad in Ridwan (2008: 65), that "the application of this method is intended for investigations aimed at solving the problems that exist today". The same opinion expressed by Nasution in Ridwan (2008: 65) explains that "descriptive research is intended to give a clearer picture of social situations by focusing on certain aspects and often showing the influence between various variables.

In the present study population is taken is a whole component of the research object, namely $f$ actor camat inhibiting performance in infrastructure development in rural sub-district sidorukunRandangan Pohuwato, sample withdrawal technique determined by purposive sampling and then the results of the data will be processed and analyzed qualitatively. While the sample in this study is

1. Community Leaders: 5 people

2. Youth figure: 5 people

3. NGO: 1 people

4. Village head: 1 people

5. Hamlet head: 3 people 
So the sample of this study amounted to 15 people

The data collection in this study consisted of observations, interviews, questionnaires and documentation. To get better data in the sense of being close to reality (objective), of course, a good data collection instrument is needed and more importantly there is a valid and reliable (reliable) measuring instrument. And for that it can be believed that the instrument or measuring instrument used is valid and reliable, then the instrument before use must be tested qualitatively and produce objective data.

Data obtained in the field will be analyzed in a qualitative manner. Qualitative analysis is used to describe the efforts made in the form of the Village Head's Performance in Infrastructure Development in Sidorukun Village, RandanganSubdistrict, Pohuwato Regency, as well as the inhibiting factors of the Village Head's Performance in the Infrastructure Development of Sidorukun Village, Randangan District, Pohuwato Regency .

\section{Findings and Discussion:-}

Inhibiting Factors in the Performance of Village Heads in Infrastructure Development of Sidorukun Village, District of Randangan, PohuwatoRegency .

As it is known that development is not only a government effort or a community, but a joint activity whose results are expected to give prosperity and prosperity to all levels of society. The success of Sidorukun village development is a reflection of the success of national development, because of that the emphasis of national development is placed on the development of sub-districts.

If the development is carried out in the sub-district area, it is clear that the participation of the sub-district community is the key to its success. However, the role of the community in the development process is certainly a lot of factors that influence the level of involvement in development, according to the author the factors that influence the participation of the community in development in Sidorukun village, Randangan sub-district are internal factors which include awareness, education and income / income. While external factors include government leadership and equipment / facilities.

\section{Internal factors which include:} Awareness / Willingness Factors

Participation in a strength of development does not arise just like that but because of what drives it to participation. One of them is the public awareness factor itself. If the community members are aware of the importance of development, then obviously they will also involve more in it. This is so that what can be achieved is the goal of development that is to provide prosperity to all citizens, as well as the community in Sidorukun Village, Randangan Sub-district which is the location of this study.

The reason respondents gave answers to personal awareness factors that were the drivers of the community for participation in development because of a concern or awareness to get involved both directly and indirectly in the development. In accordance with the results of the interview that illustrates that:

"The reason we participated is because we still have a high sense of solidarity with fellow citizens to help each other. We are also accustomed to working together. But sometimes it is constrained because there is someone working ... "(interview 27 November 2017).

Whereas what was revealed by the village head, Sidorukun. who said that;"It is rare for people to make contributions in the form of material. They prefer to give money, because they don't bother. But there are also those who do provide materials such as wood, sand, stone and others. "(Interview on November 17, 2017)

Based on data obtained from several respondents that the goods donated in the construction, usually in forms such as sand, stone, wood planks and logs. This indication shows that how much awareness of the community in Sidorukun village, Randangan sub-district, to participate in development.The inhibiting factors of the village head's performance in infrastructure development are inter-factors, internal factors which mean there is community awareness or will and a new program such as the RASDA program leads the new executor as a supplier of rice called the local Gapoktan. InProSuLa (the Institute for Promoting Sustainable Livelihood Approach) takes a major role in the design, the initiation, and the assistance in the implementation of the program. Those stages will then be measured by the government. The opportunity for public participation in the development process is a manifestation of good governance. (Fandaru, 2016) . 
With the existence of such programs, there is a limiting factor in the performance of the village head through the approach of the RASDA program conducted by Fandaru, with his research A New Design of Raskin Program (An Analysis of the RASDA Implementation in Kulonprogo Regency). In the research conducted, it provides a new design. The involvement of entrepreneurs in Gapoktan as BULOG partners is proof to improve the RASKIN program well. The Sidorukun infrastructure village sub-district views the regency of Pohuwato not only in terms of community awareness but the value of mutual cooperation

The concept of village development carried out by the government saw the Village Law No. 6 of 2014. Seeing this can actually have a major impact on the performance of the village head, the regulation or regulation is too much there is a Minister of Home Affairs Government Regulation.

If the obstacle performance of the village head in the development of village infrastructure other than internal factors or the existence of regulations by the government, the concept of setting the value or culture of the local community in the tribal Sidorukun village there are various ethnic groups, namely Java, Bali, Gorontalo and Minahasa and Bugis. This ethnicity is a high level of mutual cooperation, the concept of researchers offers in the picture below.

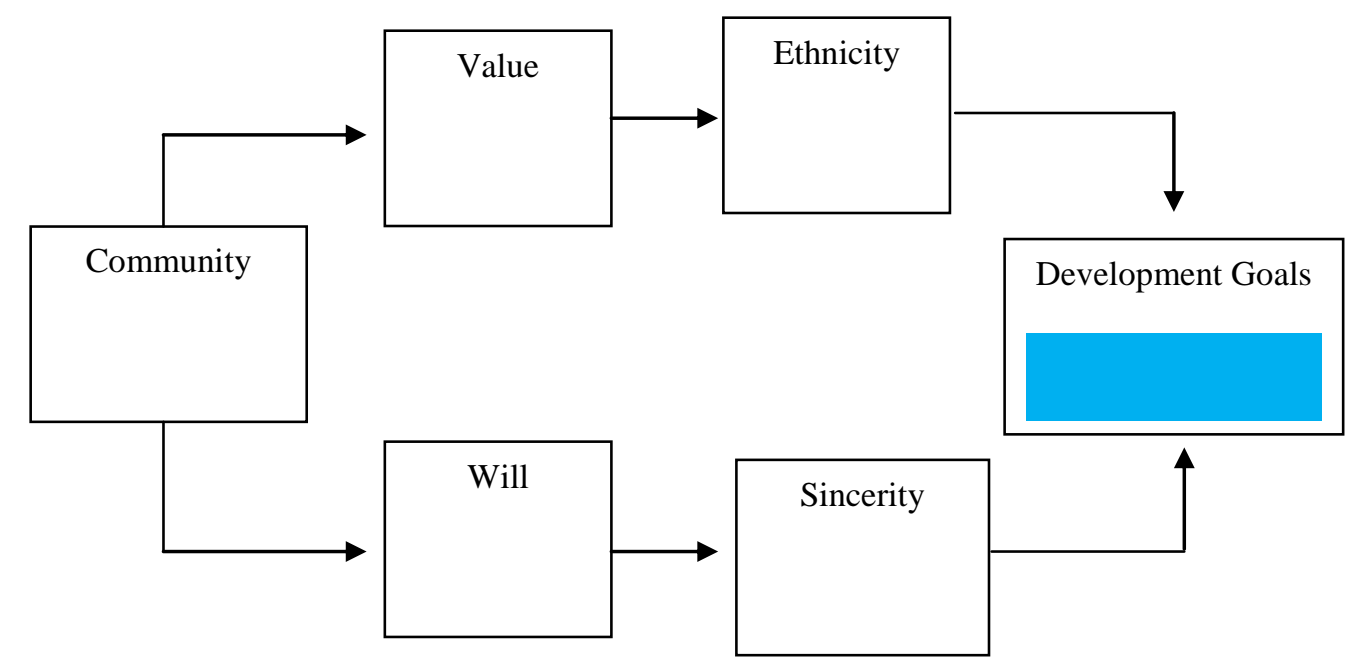

Figure 1:-Performance of Village Heads in Village Infrastructure DevelopmentSource: Identification of researchers

Looking at the picture above the village will have nothing to hamper in the performance of the village head, this has an impact on the development goals that exist in different villages as the concept of village development applied by the government actually inhibits the performance of the village head in village infrastructure development because there is no value given government. In the implementation of village development it is important to prioritize togetherness, kinship and mutual cooperation in order to realize mainstreaming of peace and social justice. The spirit of village development is given the right to make decisions about development to be carried out at the village level according to the needs of the village community contained in the planning document and then the village is given resources to carry out the development.

\section{External Factors which include:}

\section{Government Leadership}

It has been stated in the previous section that community participation and development in Sidorukun Village, RandanganSubdistrict in particular did not arise as a result of being affected by several factors and one of them is the leadership of the local government. Because the community is an alloy of several individuals who have different characteristics / characters different, then to combine it, a strength is needed, namely the ability to dynamize by government leaders, in this case the village government. Good leadership and able to unite with the character of the community led in mambina and direct the community to participate in development. But there will be the opposite if the leadership applied by the government is contrary to the nature and character of the people they lead. 
This is in accordance with the description of the Randanagan sub-district head, which stated that:

"The development seen in the ability of the villagers to develop has been improved in Sidorukun village, Randanagan sub-district, most of which are musrembang results that have been carried out with the community. Indirectly the ideas and ideas of development were originally part of the participation of the community of Randangan sub-district, so they 'the community' did indeed participate "(interview, 15 November 2017)

"I try to make the development planning process as much as possible, as far as possible, the community as a whole, but because of the busyness and limited space, I don't invite all of them, yet their aspirations have been accommodated in the list of priority list of Neighborhood Association/ Citizens Association activities, I'm sure they understand." Interview 11 November 2017)

Whereas Hasbi, a resident of Sidaman village, Randangan sub-district said that:

"Not all existing development programs can be implemented in Randanagan sub-district, Randangan sub-district Sidorukunvillagedevelopment still pay attention to the condition of the community, the environment, and the benefits of development that will be laksnaka, besides not all existing development, we" Community "can actively participate, because you really have to see if the development is aimed at us or not "(interview, 30 November 2017)

All programs needed by budget participants who are active in the performance of village heads in the development of village infrastructure can be increased by the participation of the government, both the central government and the village, this also requires a large budget. In the preparation of the budget can affect performance. Correspondingly, the research was carried out by AnggiPrasetyoWibowo and NurHandayani with the title of the research "Factors that affect the performance of the Surabaya City Government apparatus" with the conclusion that testing the effect of public accountability on the performance of local government officials produces a significance value of 0.032 , the value is more small of 0.05 , this means that public accountability has a positive effect on the performance of government officials. Testing the effect of the clarity of budget targets on the performance of local government officials resulted in a significance value of 0.044 , this value is less than 0.05 , this means that the clarity of budget targets has a positive effect on the performance of local government officials. (Anggi\&Handayani, 2017) .

The success of the community participating in development requires leadership that can be integrated with the attitude and character of the local community, because with good leadership and directed by the government it will obviously encourage the community to obey and obey the government and development policies will be carried out properly without feeling coercive or forced. With that, besides participation, there needs to be a policy that is carried out by the government so that the performance of the Village Head in the Infrastructure Development of Sidorukun Village, RandanganSubdistrict, Pohuwato Regency can advance, such as the purchase of agricultural income from the village community. Sidorukun village, the income of its people, supplying other agricultural products, for example, is one of several of these mainstays even for corn.

The government can provide assistance to farmers, both in the form of equipment, working capital, and education and counseling. We even submit these assistance directly to farmers without going through any parties or without going through many hands. This is so that this little help can be more on target while avoiding pieces here and there, one of the main obstacles to maximizing this agricultural potential is the problem of human resources, especially for farmers. The reason is that all this time farmers in the village are still farming in a very traditional way. This is mainly due to the farmers being untouched by technology and agricultural cultivation. To familiarize farmers with technology is not easy. This is because until now some farmers are also not ready with technology. We admit that there are still many farmers who are not even ready to accept the presence of technology.Frankly, this is also an obstacle for us. Not only to farmers, in general the problem of human resources also occurs in almost all sectors, such as mining and fisheries. Indeed, fisheries are one of the other great potentials. In this way, government purchasing price policies are needed so that farmers get prices in accordance with the applicable government purchase price (HPP), purchases according to the available budget. (Arjayanti, 2010)

\section{Conclusion:-}

Inhibiting factors on the performance of the village head in infrastructure development in Sidorukun village, Randangan sub-district, Pohuwato regency, where internal factors are factors of awareness or willingness and external factors that govern government leadership and need to increase the active participation of the community in development, in order to have a sense of community responsibility towards higher development and capability. For 
villagers are more developed and developed can be improved and awareness or willingness to have the soul adaptive leadership. There needs to be an improvement in the performance of the village head in infrastructure development in Sidorukun village and the formation of a regional regulation that regulates the coordination of community empowerment activities, the implementation of peace and public order. thirteen (13) subdistricts in Pohuwato district so that the Camat performance evaluation in development is better in the future and input materials for performance improvement, especially in the builder village infrastructure, to be better in the future and gain insight

\section{References:-}

1. AgusDwiyanto .( 2006 ). Realizing Good Geovernance Through Public Service k . Yogyakarta: UGM Press .

2. Anggi, PW, \&Handayani, N. (2017). Factors Affecting the Performance of Surabaya City Government Officials . Journal of Science and Accounting Research, 6 (7).

3. Arjayanti, S. (2010). Analysis of Grain / Rice Price Stability Policy at the Farmer Level in DIY Province. Journal of Policy and Public Administration, 15 (2), 17-34.

4. Bernardin, HJ \&Russel, JEA (1993). Human Resource Management and experiential approach. Singapore: McGraw-Hill, Inc.

5. Fandaru, RR (2016). A New Design of Raskin Program. Journal of Public Policy and Administration, 20 (1), 68-83.

6. Hanim, L., Hakim, A., \& Sukanto. Factors Affecting Performance. Journal of Public Administration, 2 (2), 350354.

7. Hessel, Nogi. ( 2005 ) . Public Management. Jakarta: PT GramediaWidiasarana .

8. Keban, T. Yeremias. 2004. Six Strategic Dimensions of Public Administration, Concepts, Theories and Issues. Gava Media. Yogyakarta

9. Ndraha, Taliziduha. (1999). Dimensions of the Village Government. Jakarta: Bumi Aksara.

10. Octariani, D., Akram, \&Animah. (2017). Good Governance, Performance Based Budgeting, And Skpd Budget Quality. Journal of Public Policy and Administration, Vol. 21 (2), 126-141.

11. Prawirosentono.S, ( 1999 ) . Human Resource Management, Employee Performance Policy. BPFE, Yogyakarta.

12. Riduwan ( 2008 ). Methods and Techniques for Composing Thesis . CV. Alfabeta, Bandung.

13. Republic of Indonesia. (2003). Law Number 17 of 2003 concerning State Finance. Republic of Indonesia. (2014). Act No. mor 62014 About the village

14. Republic of Indonesia. (2008). Government Regulation Number 19 of 2008 concerning Districts .

15. www.google.co m. (2017). Government development concept. Retrieved. April 21, 2018. From www.google.com/2018/04. 